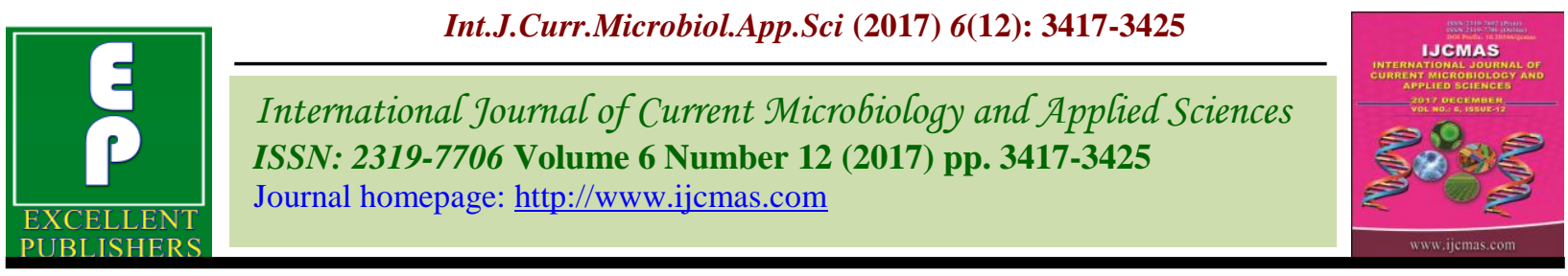

Original Research Article

https://doi.org/10.20546/ijcmas.2017.612.397

\title{
Evaluation of Agaricus bisporus Lange (Sing.) Strains in the Plains of Punjab, India
}

\author{
Mohini Prabha Singh", Sabhjeet Kaur and H.S. Sodhi \\ Department of Microbiology, Punjab Agricultural University, Ludhiana-141004, Punjab, India \\ *Corresponding author
}

\section{A B S T R A C T}

Twelve strains of Agaricus bisporus (Lange) Sing. (AVT 01- AVT 06, AVT 07-AVT 11 and U3) were screened for their yield potential with the objective of selecting them to grow best in Punjab conditions. These strains with fifteen white strains (SSI01/12-

\section{Keywords}

Agaricus bisporus, Wheat straw, Yield potential, Stipe, Pileus.

\section{Article Info}

Accepted: 26 October 2017 Available Online: 10 December 2017 SSI15/12) were checked for quality parameters (color, texture, stipe length and pileus diameter) to select for post-harvest processing such as canning and pickling. Cultivation was carried on short method compost using wheat straw as substrate. Out of white strains, AVT $02(18.27 \mathrm{~kg} / 100 \mathrm{~kg}$ compost) gave maximum yield followed by AVT 06 (14.30kg/100kg compost). From brown strains, AVT 11 gave maximum yield of $10.78 \mathrm{~kg} / 100 \mathrm{~kg}$ compost followed by AVT 08 giving $8.30 \mathrm{~kg} / 100 \mathrm{~kg}$ compost. The color index indicated maximum L Value for six strains SSI07/12, SSI09/12, SSI12/12, AVT 02, AVT 04 and AVT 06 with minimum values for brown strains ranging from 30.00 to 31.15. Texture analysis indicated the hardness maximum for white strains SSI08/12 followed by six other strains SSI02/12, SSI06/12, SSI12/12 and U3 while brown strains showed less hardness. The average stipe length varied significantly as short as $2.10 \mathrm{~cm}$ in strain SSI12/12 and as long as $4.0 \mathrm{~cm}$ in strains SSI03/12 and SSI15/12 (white strains) while among brown strains, it is shortest for AVT-10 $(2.40 \mathrm{~cm})$ and longest for AVT-08 $(3.50 \mathrm{~cm})$.There is non- significant difference in the diameter of the pileus for all the white and brown strains of Agaricus bisporus. These strains showed a correlation of better yield with good color and textural properties.

\section{Introduction}

Agriculture has been a main strength of Indian economy but a struggle is still on to achieve nutritional security demand following secondary agricultural vocations. To meet such challenges, diversification in the agricultural activities which include mushroom production is important to address the problems of quality food, health and environmental sustainability.

Mushrooms represent microbial technology that recycles agricultural, industrial, forestry and household waste into food and manure.
Mushroom farming, today, is being practiced in more than 100 countries and its production is increasing at an annual rate of $6-7 \%$. Presently, three geographical regions-Europe, America and East Asia contribute to about $96 \%$ of world mushroom production. China leads in mushroom production and USA is the second largest producer sharing $16 \%$ of the world output (Prakasam, 2012). In most countries, mushrooms like Agaricus bisporus, Auricularia spp., Lentinus edodes, Pleurotus spp., Volvariella volvaceae, etc. are commonly acceptable for cultivation (Diez 
and Alvarez, 2001). The button mushroom, Agaricus bisporus, is one of the most extensively cultivated mushroom in the world. It belongs to phylum Basidiomycota, class Agaricomycetes, order Agaric ales and family Agaricaceae. The most suitable temperature of the mycelium is $24-25^{\circ} \mathrm{C}$, while $16-18^{\circ} \mathrm{C}$ is essential for the formation of fruit bodies. It is cultivated in northern plains as well as coastal plateaus of South India. India produces about 600 million tonnes of agricultural byproducts, which can profitably be utilized for the cultivation of mushrooms. Currently, we are using $0.04 \%$ of these residues for producing around 1.2 lakh tonnes of mushrooms of which $85 \%$ is button mushroom.

India contributes about $3 \%$ of the total world button mushroom production. Two-three crops of button mushroom are grown seasonally in temperate regions with minor adjustments of temperature in the growing rooms, while one crop of button mushroom is raised in north western plains of India seasonally. Mushrooms are popularly grown in Punjab, Uttarakhand, Haryana, Uttar Pradesh, Tamil Nadu, Himachal Pradesh, Orissa, Andhra Pradesh, Maharashtra, Kerala and North eastern regions of India. Punjab alone produces $45-48 \%$ mushrooms (Singh et al., 2011).

Productivity and quality of widely cultivated Agaricus mushrooms are mainly dependent on the strain and substrates used. Four differentiated commercial mushroom strains exist in the market: 1) pure white strains, 2) off-white strains with large white mushrooms 3) hybrid strains 4) brown strains (Fritsche and Sonnenberg, 1988). The actual cap characteristics of these strains regarding size, shape, and color are strongly influenced by environmental and cultivation conditions (Tschierpe, 1983). In India, a number of commercial strains like S-11, S-130, S-140,
S-649, S-791, CM-1, CM-5, CM-10 (hybrid), A-15 (sylvan, hybrid), U-3, X-13, Delta, etc. have been used for cultivation whereas in Punjab, S-11 and U3 are preferably cultivated (Kapoor, 1989).

Our environment is conducive for A. bisporus cultivation due to abundant availability of straw and plant residues. It is able to degrade the major polymers of woody plant materials; cellulose, hemicelluloses, and lignin (at least to some extent). Several formulations can be used for production of Agaricus sp. which is usually determined by the availability and cost of substrates (Sanchez and Royse, 2001). Straws (rice, wheat, oat and barley), byproducts (sugarcane bagasse), horse and chicken manure are the most important components used as lignocellulosic sources incomposts (Minhoni et al., 2005; Peil et al., 1995).

The preparation of mushroom compost has for many years been divided into distinct phases, phase I during which raw material are mixed, wetted and stacked with considerable dry matter losses, and phase II, which includes pasteurization and conditioning treatment to produce a selective and pathogen free substrate (Ross and Harris, 1983). This process of composting is catalysed by bacteria and fungi (Koschinsky et al., 1998).

The production and quality parameters for mushrooms include: number, size, earliness, freshness, color, shape, firmness, aroma, freedom from debris, the degree of maturity, development stage and visual defects (Carey and O'Connor 1991; Pardo, 1999). Any change in one or more of these factors may affect acceptability by the consumer. Like with most horticultural products, mushrooms have a limited storage life ( 1 to $3 \mathrm{~d}$ at $18^{\circ} \mathrm{C}$ ) and that quality is affected by cultivation techniques, the strain, handling, and storage conditions (Burton, 1989). Freshly harvested 
mushrooms have a very high respiration rate and water content which make them prone to microbial spoilage while high tyrosinase and phenolic content makes them susceptible to enzymatic browning (Brennen et al., 2000). This leads to loss in texture, off flavor development and discoloration resulting in poor marketable quality and restricts trade of fresh mushrooms (Mehta et al., 2011).

Therefore, to extend their marketability and availability to the consumers, fresh or processed form is of great significance (Bhupinder and Ibitwar, 2007). Drying, canning and freezing are initially accepted methods of mushroom preservation. Value added products such as pickle, murabba also help in long term storage. Keeping in view the above mentioned points, present study was planned to evaluate the white and brown strains of Agaricus bisporus in Punjab region for selecting high yielding strains and to test their color and texture properties for postharvest processing.

\section{Materials and Methods}

\section{Procurement of cultures}

Agaricus bisporus Lange (Sing.), strains AVT 01- AVT 06 (white), AVT 07-AVT 11 (brown) and SSI01/12- SSI15/12 (white) were procured from DMR, Solan and strain U3 was obtained from Department of Microbiology, Punjab Agricultural University, Ludhiana. The cultures were maintained on potato dextrose agar (PDA) medium at $4^{\circ} \mathrm{C}$.

\section{Spawn preparation}

For cultivation trial, wheat grain spawn was prepared using the standard methodology of Garcha, (1994). Wheat grains were washed and boiled for 35-40 minutes and then excess water was drained. The grains were then $\begin{array}{llllll}\text { mixed with } & 2 \% & \mathrm{CaCO}_{3} & \text { and } & 4 \% & \mathrm{CaSO}_{4}\end{array}$ powder, filled in bottles and steam sterilized at 20 psi for 90 minutes. After cooling overnight, the bottles were inoculated using 14-15 days old culture bit of size $3 \times 1 \mathrm{~cm}$, incubated at $25 \pm 1^{\circ} \mathrm{C}$ until the mycelial growth impregnated the grain (@ 20 days incubation).

\section{Composting and spawning}

Wheat straw based compost was prepared using short method of composting (Khanna and Kapoor, 2007). The spawning was done using polythene bags (20, $x$ 24, ) filling $10 \mathrm{~kg}$ compost in each bag and spawned @ 70 g/ bag by thorough mixing. Four replicates of each strain with ten bags for AVT 01-AVT 11 and U3 strains were laid in random block design (RBD).

\section{Casing and harvesting}

Casing soil was prepared by mixing well decomposed (2 yrs old) Farmyard Manure (FYM) and spent compost (SC, 2 yrs old) in 2:1 (v/v) ratio adjusted to $\mathrm{pH} 7.5$ with $\mathrm{CaCO}_{3}$. Bags fully impregnated with mycelium were covered with the casing soil to make $4 \mathrm{~cm}$ thick uniform layer using $2 \mathrm{~kg}$ casing soil per bag. Adequate humidity (=RH 70-90\%) was maintained by spraying water on the bags twice a day. Very little or no ventilation was provided until the first appearance of the pinheads. Thereafter, intermittent crossventilation was given for total 4-8 hour/ day. The mushrooms were harvested by gentle twisting of the fruit body. A record of total yield, number of opened mushrooms in each harvest and average fruit body weight was made to determine the quality of mushrooms produced.

\section{Morphological observations}

Freshly harvested Agaricus bisporus Lange (Sing.), strains AVT 01- AVT 06, AVT 07- 
AVT 11 (brown), SSI01/12-SSI15/12 and U3 were subjected to morphological examinations (stipe length, stipe diameter, color, texture) for their acceptance as postharvest processed products to improve shelf life.

Stipe length and Pileus diameter: The stipe length $(\mathrm{cm})$ and diameter $(\mathrm{cm})$ of freshly harvested mushrooms were measured with metre rule. The mushroom pileus diameter was taken from one end of the pileus to the other passing through the centre of the pileus.

The pileus diameter was obtained on 5 randomly picked mushrooms, from the harvest and then the average pileus diameter was calculated for a given harvest.

The length of stipe was measured by placing the ruler from one end where it was attached to the substrate to the point where the gills on the pileus start on the stipe to get the length in centimetres $(\mathrm{cm})$. The average for that day's harvest was then calculated using 5 readings.

Color analysis: Color of the mushroom pileus was estimated using the CIELAB scale at an observer angle of $10^{\circ}$ with a Mini scan XE plus Hunter Lab Colorimeter.

The ' $a$ ' value determines greenness $(a<0)$ or redness (a $>0$ ) and the ' $b$ ' value determines blueness $(b<0)$ or yellowness $(b>0)$. The ' $L$ ' value varies between 0 and 100 , representing transition from black to white.

Texture analysis: Texture profile analysis (TPA) was done using a texture analyzer (model TA-XT2i; Stable Micro Systems, United Kingdom) with instrument parameters described by Kotwaliwale et al., (2007) with modification of the strain to $75 \%$ of sample height and probe $(75-\mathrm{mm}$ compression platen).The hardness was calculated as given by Bourne 1982 .

\section{Statistical analysis}

The yield obtained for various strains of Agaricus bisporus Lange (Sing.) with Random Block Design and optical properties observed were statistically analysed through ANOVA to see the critical difference at 5\% level of significance between the strains.

\section{Results and Discussion}

\section{Cultivation}

\section{On short method compost}

The cultivation trial was carried out on short method compost for all the Agaricus bisporus strains (AVT 01-11, U3). Four replicates each with ten bags for each strain were laid in random block design (RBD) to accommodate 240 bags. Beds were cased after 18-25d of spawning. Pinheads appeared in $17-24 \mathrm{~d}$ after casing. The first crop was harvested between 17-23d after casing and lasted for4 weeks. AVT 01-11 were compared on short method compost because these are advanced variety trials. From yield data (Table 1), out of white strains, AVT-02 (18.27 kg/100 kg compost) gave maximum yield followed by AVT-06 $(14.30 \mathrm{Kg} / 100 \mathrm{~kg}$ compost). From brown strains, AVT 11 gave maximum yield of $10.78 \mathrm{~kg} / 100 \mathrm{~kg}$ compost followed by AVT 08 giving $8.30 \mathrm{~kg} / 100 \mathrm{~kg}$ compost. The average weight of a mushroom ranged between 10.89 to 14.79 g. Kumar and Singh, (2013) reported maximum yield $(16.1 \mathrm{~kg} / 100$ $\mathrm{kg}$ compost) in case of wheat straw based compost. Diamatopoulou and Philippoussis, (2001) observed maximum yield $(30.84 \mathrm{~kg}$ of edible mushroom biomass) in white strain 207 among five Agaricus bisporus strains. Baysal et al., (2007) reported that the highest mushroom yield (1707.2 g) was recorded by wheat straw mixed with pigeon manure with the peat of Caykara and perlite mixture as casing material (Table 2). 
Table.1 Cultivation of Agaricus bisporus strains on short method compost

\begin{tabular}{|c|c|c|c|c|c|c|c|c|c|}
\hline $\begin{array}{c}\text { Strain } \\
\text { no. }\end{array}$ & $\begin{array}{l}\text { Spawn } \\
\text { run }(d)\end{array}$ & $\begin{array}{l}\text { Case } \\
\text { run } \\
\text { (d) }\end{array}$ & \begin{tabular}{|c|} 
Pinning \\
after \\
casing (d)
\end{tabular} & $\begin{array}{c}\text { First } \\
\text { harvest } \\
\text { (d) }\end{array}$ & $\begin{array}{c}\text { Last } \\
\text { harvest } \\
\text { (d) }\end{array}$ & $\begin{array}{c}\text { Yield } \\
\text { (kg/100kg } \\
\text { compost) }\end{array}$ & $\begin{array}{c}\text { NFB } \\
\text { (no./100kg) }\end{array}$ & $\begin{array}{c}\text { Av.wt of a } \\
\text { FB (g). }\end{array}$ & $\begin{array}{c}\text { Disease } \\
\text { /pest }\end{array}$ \\
\hline AVT-01 & 24 & 19 & 20 & 20 & 22 & 5.26 & 362 & 14.79 & + \\
\hline AVT-02 & 23 & 17 & 19 & 19 & 21 & 18.27 & 1374 & 13.90 & - \\
\hline AVT-03 & 25 & 19 & 20 & 20 & 21 & 9.373 & 750 & 12.87 & - \\
\hline AVT-04 & 25 & 19 & 20 & 20 & 22 & 12.49 & 1058 & 12.39 & + \\
\hline AVT-05 & 22 & 16 & 18 & 18 & 19 & 8.30 & 560 & 14.06 & - \\
\hline AVT-06 & 24 & 15 & 17 & 17 & 20 & 14.30 & 1038 & 13.97 & - \\
\hline AVT-07 & 24 & 18 & \multicolumn{7}{|c|}{ NO PINNING NO FRUITING } \\
\hline AVT-08 & 19 & 17 & 24 & 23 & 31.0 & 8.30 & 615 & 13.5 & - \\
\hline AVT-09 & 20 & 18 & 20 & 22 & 25.0 & 5.66 & 425 & 13.3 & + \\
\hline AVT-10 & 21 & 19 & 19 & 21 & 25.0 & 6.56 & 512 & 12.8 & - \\
\hline AVT-11 & 18 & 16.5 & 19 & 21 & 36.5 & 10.78 & 823.5 & 13.08 & - \\
\hline $\mathrm{U} 3$ & 19.5 & 16.5 & 20 & 22.5 & 38.0 & 11.94 & 1632 & 10.89 & - \\
\hline $\mathrm{CD}(5 \%)$ & & & & & & 0.18 & 6.58 & & \\
\hline
\end{tabular}

Bag size: 20»x 24» (Polythene, 150 gauge); No. of replicates: 4 each for one strain with 10 bags (10kg compost/bag); Experimental design: RBD; Date of spawning: 6.1.13-8.1.13; Rate of spawn: 0.7\% wet compost (70g/bag of 10kg compost); Days of spawn run: 18-25d; Casing: FYM +SC (2:1 v/v); Date of casing: 28.1 .13 31.1.13; Days of case run: 15-18 d; Days for pinning: 17-24 d after casing; Days for first harvest : 17-23 d after casing; Days for last harvest: 4 weeks crop data ; NFB: number of fruit bodies.

Table.2 Cultivation of Agaricus bisporus strains on short method compost (Kaur et al., 2014)

\begin{tabular}{|l|l|l|l|l|l|l|l|l|}
\hline Strain & $\begin{array}{l}\text { Spawn } \\
\text { run }(\mathbf{d})\end{array}$ & $\begin{array}{l}\text { Case } \\
\text { run }(\mathbf{d})\end{array}$ & $\begin{array}{l}\text { Pinning } \\
\text { after } \\
\text { casing }(\mathbf{d})\end{array}$ & $\begin{array}{l}\text { First } \\
\text { harvest } \\
(\mathbf{d})\end{array}$ & $\begin{array}{l}\text { Last } \\
\text { harvest } \\
(\mathbf{d})\end{array}$ & $\begin{array}{l}\text { Yield } \\
(\mathbf{k g} / \mathbf{1 0 0 k g})\end{array}$ & $\begin{array}{l}\text { NFB } \\
(\mathbf{n o . / 1 0 0 k g})\end{array}$ & $\begin{array}{l}\text { Av. Wt. } \\
\text { of a FB } \\
\text { (g) }\end{array}$ \\
\hline SSI01/12 & 15 & 16 & 18 & 20 & 21 & 13.46 & 1246 & 10.8 \\
\hline SSI02/12 & 15 & 16 & 18 & 20 & 21 & 14.80 & 1203 & 12.3 \\
\hline SSI03/12 & 18 & 17 & 19 & 22 & 21 & 5.64 & 440 & 12.8 \\
\hline SSI04/12 & 15 & 19 & 20 & 23 & 21 & 18.22 & 1612 & 11.3 \\
\hline SSI05/12 & 17 & 16 & 18 & 20 & 21 & 5.44 & 375 & 14.5 \\
\hline SSI06/12 & 18 & 17 & 18 & 22 & 21 & 13.20 & 892 & 14.8 \\
\hline SSI07/12 & 18 & 19 & 20 & 22 & 21 & 10.14 & 700 & 14.5 \\
\hline SSI08/12 & 17 & 18 & 20 & 21 & 21 & 17.94 & 1401 & 12.8 \\
\hline SSI09/12 & 21 & 19 & 20 & 21 & 21 & 5.40 & 357 & 15.1 \\
\hline SSI10/12 & 18 & 19 & 20 & 22 & 21 & 7.20 & 507 & 14.2 \\
\hline SSI11/12 & 18 & 19 & 20 & 22 & 21 & 6.54 & 467 & 14.0 \\
\hline SSI12/12 & 18 & 19 & 20 & 22 & 21 & 7.70 & 616 & 12.5 \\
\hline SSI13/12 & 17 & 19 & 20 & 23 & 21 & 7.62 & 544 & 14.0 \\
\hline SSI14/12 & 16 & 18 & 20 & 22 & 21 & 10.64 & 744 & 14.3 \\
\hline SSI15/12 & 18 & 19 & 20 & 22 & 21 & 5.04 & 403 & 12.5 \\
\hline CD (5\%) & & & & & 2.68 & 205 & \\
\hline
\end{tabular}

Bag size: $20 \rightsquigarrow x$ 24» (Polythene, 150 gauge); No. of replicates: 4 each for one strain with 10 bags (10kg compost/bag); Experimental design: RBD; Date of spawning: 6.1.13-8.1.13; Rate of spawn: 0.7\% wet compost (70g/bag of 10kg compost); Days of spawn run: 15-18d; Casing: FYM +SC (2:1 v/v); Date of casing: 28.1 .13 31.1.13; Days of case run: 16-19 d; Days for pinning: 18-20 d after casing; Days for first harvest : 20-23 d after casing; Days for last harvest: 4 weeks crop data ; NFB: number of fruit bodies. 
Table.3 Comparison of color, texture, stipe length and stipe diameter for Agaricus bisporus strains

\begin{tabular}{|l|l|l|l|l|}
\hline Strains & $\begin{array}{l}\text { Color } \\
\text { Value) }\end{array}$ & $\begin{array}{l}\text { Texture } \\
\text { (hardness) }\end{array}$ & $\begin{array}{l}\text { Stipe length } \\
(\mathbf{c m})\end{array}$ & Pileus diameter $(\mathbf{c m})$ \\
\hline AVT-01 & 85.54 & 1236.25 & 3.94 & 4.02 \\
\hline AVT-02 & 89.00 & 1818.50 & 2.74 & 4.36 \\
\hline AVT-03 & 83.74 & 1648.18 & 2.54 & 3.08 \\
\hline AVT-04 & 88.70 & 1093.00 & 2.78 & 3.82 \\
\hline AVT-05 & 85.55 & 1235.53 & 2.74 & 3.40 \\
\hline AVT-06 & 89.87 & 1417.02 & 2.68 & 4.02 \\
\hline AVT-07 & DID NOT FRUIT & \multicolumn{1}{|l|}{} \\
\hline AVT-08 & 31.13 & 1312.9 & 3.50 & 4.26 \\
\hline AVT-09 & 30.00 & 1066.2 & 2.78 & 3.82 \\
\hline AVT-10 & 30.21 & 971.90 & 2.40 & 3.64 \\
\hline AVT-11 & 31.15 & 1489.6 & 2.54 & 3.88 \\
\hline U3 & 78.00 & 2098.45 & 3.90 & 4.36 \\
\hline SSI01/12 & 84.94 & 1550.96 & 2.60 & 3.08 \\
\hline SSI02/12 & 84.46 & 1990.39 & 3.40 & 3.82 \\
\hline SSI03/12 & 83.76 & 1073.45 & 4.00 & 3.90 \\
\hline SSI04/12 & 86.58 & 783.42 & 2.80 & 3.82 \\
\hline SSI05/12 & 85.73 & 792.35 & 2.68 & 3.88 \\
\hline SSI06/12 & 87.19 & 1910.07 & 3.90 & 4.26 \\
\hline SSI07/12 & 90.85 & 1525.85 & 2.40 & 3.4 \\
\hline SSI08/12 & 87.44 & 2575.34 & 3.94 & 3.64 \\
\hline SSI09/12 & 90.78 & 1545.78 & 2.60 & 4.00 \\
\hline SSI10/12 & 84.52 & 1234.50 & 3.40 & 4.26 \\
\hline SSI11/12 & 85.95 & 1158.75 & 3.50 & 3.84 \\
\hline SSI12/12 & 91.26 & 1924.08 & 2.10 & 4.00 \\
\hline SSI13/12 & 86.56 & 1453.23 & 2.80 & 3.84 \\
\hline SSI14/12 & 87.25 & 1125.55 & 3.10 & 3.90 \\
\hline SSI15/12 & 84.64 & 1123.75 & 4.00 & 4.00 \\
\hline CD & 3.20 & 2.99 & 0.87 & NS \\
\hline
\end{tabular}

\section{Morphological and optical parameters}

Twelve strains of Agaricus bisporus (Lange) Sing. (AVT 01- AVT 06, AVT 07-AVT 11 and U3) along with fifteen white strains (SSI01/12- SSI15/12) were checked for quality parameters (color, texture, stipe length and pileus diameter) to select strains for postharvest processing such as canning and pickling.

\section{Color and texture analysis}

The color determination showed that $\mathrm{L}$ Value was maximum for six strains SSI07/12, SSI09/12, SSI12/12, AVT 02, AVT- 04 and
AVT- 06 with minimum values for brown strains ranging from 30.00 to 31.15 . Texture analysis indicated the hardness as a main quality parameter which was maximum for strain SSI08/12 (2575g). When compared with white strains, brown strains showed less hardness (Table 3). The strains showed a correlation of better yield with good color and textural properties. Among white strains, SSI04/12 (86.58), SSI08/12 (87.44), AVT-02 (89.00) and AVT-06 (89.97) showed better color index which was close to the highest value of L (90.85) while brown strains had the similar L Values ranging from 30.00 to 31.15. The hardness was maximum for SSI08/12 (2575g) followed by AVT-02 (1818.50g) 
among white strains while in case of brown strains AVT-11 showed maximum texture (1489.60g) followed by AVT-08 (1312.90g). These strains also gave better yield. The results were similar to the study done by Kumar and Suman, (2014) where significant variations in the morphological traits of various strains, like color and toughness of a fruit body was seen. Monolopoulou et al., (2007) also found that the mushroom whiteness assessment allowed the characterization of most strains as well as their acceptance among wholesalers.

\section{Stipe length and pileus diameter}

The stipe length varied significantly from strain to strain. The average stipe length recorded as short as $2.10 \mathrm{~cm}$ in strain SSI12/12 and as long as $4.0 \mathrm{~cm}$ in strain SSI03/12 and SSI15/12 (white strains) while among brown strains, it is shortest for AVT$10(2.40 \mathrm{~cm})$ and longest for AVT-08 $(3.50 \mathrm{~cm})$. Stipe length is the most important character of button mushroom, as shorter the stipe length, better the quality. SSI04/12 $(2.80 \mathrm{~cm})$ and AVT-02 $(2.74 \mathrm{~cm})$ have small stipe length which is also correlated with their high yield obtained through short composting. There is non-significant difference in the diameter of the pileus for all the white and brown strains of Agaricus bisporus. The average range of pileus diameter varies from 3.08 to 4.36 . These observations were similar to the data obtained from Prakasam and Singh, (2008), where the average stipe length recorded as short as $17.60 \mathrm{~mm}$ in strain NCB13 and as long as $37.30 \mathrm{~mm}$ in strain $\mathrm{X}-13$ while no significant differences in pileus diameter among the strains were obtained. The maximum diameter was observed in strain Delta $(35.20 \mathrm{~mm})$ and minimum was observed in strain CM-10 (26.20mm). The observations were also in agreement with the work carried by Kumar and Suman (2014) where strain DMRA-7, in addition to being high yielding also exhibited better morphological quality traits followed by strains DMRA-37, DMRA-102 and U3. Different test strains exhibited different morphological qualities in addition to their yield. Strain DMRA-7 exhibited best morphological qualities, while other strains gave one or more acceptable qualities, but failed to exhibit all the best qualities. There were significant variations in the morphological traits of various strains, like stipe length, stipe diameter, pileus diameter, color, toughtness and average weight of fruit body.

On the basis of results obtained, it can be concluded that AVT 02 (White strain) and AVT 11(Brown strain) gave maximum yield on wheat straw based compost through short method of composting. The strains showed a correlation of better yield with good color and textural properties. AVT 02 and AVT 06 showed better color index which was close to the highest value of L (90.85). AVT 02 among white strains and AVT 11 among brown strains showed maximum texture. Length of stipe is correlated with yield as shorter the stipe length, better the quality. SSI04/12 and AVT-02 with small stipe gave high yield. These strains, thus, have been further selected for post-harvest processing such as canning and pickling.

\section{References}

Baysal, E., O. N. Yigitbasi, M. Colak, H. Toker, H. Simsek, and Yilmaz, F. 2007. Cultivation of Agaricus bisporuson somecompost formulas and locally available casing materials. Part I: Wheat straw based compost formulas and locally available casing materials. African Journal of Biotechnology, 6: 2225-2230.

Bhupinder, K., and Ibitwar, B.B. 2007. Mushroom cultivation and processing. 
Science Technology Entrepreneur. pp. $1-12$.

Bourne, M. C. 1974. Textural changes in ripening peaches. J Can Inst Food Sci Tech. 7: 11-15.

Brennan, M., G. L. Port, and Gormley, R. 2000.Post-harvest treatment with citric acid or hydrogen peroxide to extend the shelf life of fresh sliced mushrooms. Leben Wissench Tech. 33: 285-289.

Burton, K. S. 1989. The quality and storage life of Agaricus bisporus. Mush Sci 12:287-293.

Carey, A. T., and O'Connor, T. P. 1991. Influence of husbandry factors on the quality of fresh mushrooms (Agaricus bisporus). Mush Sci 13:673-682.

Diamantopoulou, P., and Philippoussis, A. 2001. Production attributes of Agaricus bisporus white and off-white strains and the effect of calcium chloride irrigation on productivity and quality. SciHortic. 91: 379-391.

Diez, V. A., and Alvarez, A. 2001.Compositional and nutritional studies on two wild edible mushrooms from Northwest Spain. Food Chem 75: 417-422.

Fritsche, G., and Sonnenberg, A. S. M. 1988. Mushroom strains. In: Van Griensven LJLD, editor. The cultivation of mushrooms. Interlingua T.T.I. Ltd., East Grinstead, Sussex, UK., p. 101-123.

Garcha, H. S. 1994. Mushroom growing, PAU Ludhiana. pp. 60.

Kapoor, J. N. 1989. Introduction. Mushroom cultivation Published by Indian Council of Agricultural Research, New Delhi. 1: $1-6$.

Kaur, S., S. Kapoor, and Sodhi, H. S. 2014. Screening and Evaluation of Agaricus bisporus (Lange) Sing. Strains for temperature variability. Int J Current Microbiol and Appl. Sci., 3(6): 120-127.

Khanna, P. K., and Kapoor, S. 2007. A manual on mushroom production. Pp.
26-31.

Koschinsky, S., F. Schwieger, S. Peters, K. Grbbe, and Tebbe, C.C.1998. Characterizing microbial communities of compost at DNA level. Med FacL and bouww Uni Gent., 63: 1725-1732.

Kotwaliwale, N., P. Bakane, and Verma, A. 2007. Changes in textural and optical properties of oyster mushroom during hot air drying. J Food Engg., 78: 12071211.

Kumar, A., and Singh, S. 2013. Evaluation of paddy and wheat straw based compost during seasonal cultivation of button mushroom. Proc of Indian Mush Confpp, Pp. 51-52.

Kumar, V., and Suman, B. C. 2015. Molecular characterization of Agaricus bisporus strains and their evaluation for production efficiency. Indian Phytopath 67(4): 412-417.

Manolopoulou, E., A. Philippoussis, G. Lambrinos, and Diamantopoulou, P. 2007.Evaluation of Productivity and Postharvest Quality during storage of five Agaricus bisporus strains. J Food Quality, 30: 646-663.

Mehta, B. K., S. K. Jain, G. P. Sharma, A. Doshi, and Jain, H. K. 2011. Cultivation of button mushroom and its processing: An techno-economic feasibility. Int. J. Adv. Biotech. Res., 2: 201-207.

Minhoni, M. T. A., F. J. Kopytowski, and Andrade, M. C. N. 2005.Cultivo de Agaricusblazei Murrill ss. Heinemann. Fundação de Estudos e Pesquisas Agrícolas e Florestais, Botucatu, p. 141.

Pardo, A. 1999. Respuestasagronómicas de diferentes materiales de cobertura para el cultivodelchampin o'n [Agaricus bisporus (Lange) Imbach]. PhD thesis, Universidad de Castilla- La Mancha, Albacete.

Peil, R. M., E. A. Rosseto and Rocha, M. T. R. 1995. Rendimento do cogumelo Agaricus bisporus (Lange) 
Imbachemtrês formulações de compostos. Rev Bras Agrociência, 1 (3): 163-166.

Prakasam, V. 2012. Current scenario of mushroom research in India. Indian Phytopath, 65 (1):1-11.

Prakasam, V., and Singh, R. P. 2008.Cultural and Morphological Characterization of Agaricus bisporus strains. Ann $\mathrm{Pl}$ Protec Sci., 16 (2): 454-457.

Ross, R. C., and Harris, P. J. 1983.The significance of thermophilic fungi in mushroom compost preparation. Sci. Hort., 20: 61-70.
Sánchez, J. E., and Royse, D. J. 2001. Adapting substrate formulas used for shiitake for production of brown Agaricus bisporus. Bioresour Tech., 77: 65-69.

Singh, M., B. Vijay, S. Kamal, and Wakcaure, G. C. 2011. Mushrooms-Cultivation, Marketing and Consumption. Directorate of Mushroom Research, Solan. pp. 266.

Tschierpe, H. J. 1983. Environmental factors and mushroom strains. Mush J132: $417-429$.

\section{How to cite this article:}

Mohini Prabha Singh, Sabhjeet Kaur and Sodhi, H.S. 2017. Evaluation of Agaricus bisporus Lange (Sing.) Strains in the Plains of Punjab. Int.J.Curr.Microbiol.App.Sci. 6(12): 3417-3425. doi: https://doi.org/10.20546/ijcmas.2017.612.397 